\title{
EDitorial
}

\section{Doenças contemporâneas: o grande leque}

\author{
Contemporary diseases; the wide range
}

Jum imensa gratidão que concluo o compilado de trabalhos desta edição, dedicada à Disciplina de Medicina do Departamento Científico da Faculdade de Medicina da Universidade de São Paulo. Como diretora e coordenadora da então Disciplina Optativa de Abordagem Prática da Escrita Científica, faço-me no dever de agradecer a todos os autores e orientadores que trabalharam junto a mim na concretização desta série de trabalhos acadêmicos. Foram matriculados inicialmente vinte e um alunos de diversas fases do curso de graduação em Medicina, divididos em sete grupos, ficando ainda alguns em lista de espera. Com o tema geral intitulado "Doenças do Mundo Contemporâneo", todos os orientadores, dentro de suas respectivas áreas de trabalho, buscaram enfatizar importantes aspectos e perspectivas que se relacionassem ao grande tema proposto. O árduo trabalho dos alunos, associado à sistematização apresentada pelos seus tutores, levaram a excelentes resultados representados nos artigos de revisão sistemática desta edição, mantendo a perspectiva de alta qualidade de nossa Revista e abrangendo importantes temas em discussão na contemporaneidade.

É sabido por todos nós o quanto a pesquisa científica é trivial ao avanço da sociedade, ainda mais considerando estarmos inseridos no contexto acadêmico da universidade e termos o dever social de mantermo-nos ativos na busca pelo bem da sociedade em todos os seus parâmetros, sejam eles civis, econômicos ou políticos. Dessa forma, o fomento à Ciência desde os primeiros anos de graduação torna-se essencial à amplificação da produção científica.

Nesse ínterim, o estímulo à produção de trabalhos, não só para a nossa estimada Revista, mas para todo o corpo científico nacional e mundial, mostra-se a base para que o papel social do cientista não se perca em meio ao grande universo acadêmico. Dentro desse papel, entram aspectos essenciais como o estímulo ao espírito crítico e a busca ativa por perguntas, e não apenas por respostas, representando o ideal, não apenas do médico, mas de qualquer profissional que se preze em sua cidadania.

Assim, concluo uma longa caminhada, certa de que todo o trabalho imposto para que tais trabalhos fossem uma realidade torna-se um grande aprendizado de que resiliência, responsabilidade e disciplina foram importantes características que me levaram à grande estima hoje de toda essa produção científica. $\mathrm{E}$, assim, finda mais esta etapa, agradecimentos deixo a meus colegas de gestão e a amigos próximos, que me auxiliaram sobremaneira durante todo o processo.

\footnotetext{
Thamara Rodrigues da Costa

Acadêmica da $103^{\mathrm{a}}$ Turma de Medicina da Faculdade de Medicina da USP, Coordenadora da Disciplina Optativa de Abordagem Prática da Escrita Científica da Revista de Medicina da FMUSP

https://orcid.org/0000-0001-7389-9748
} 